\title{
OIL CAKES AS SUBSTRATE FOR IMPROVED LIPASE PRODUCTION IN SOLID STATE FERMENTATION
}

\section{PRATYOOSH SHUKLA*, JAYA BHAGAT, SMRITI SHRIVASTAVA}

Department of Biotechnology, Birla Institute of Technology, (Deemed University) Mesra, Ranchi, 835215, Jharkhand, India ${ }^{*}$ Corresponding Author: Email- pshukla@bitmesra.ac.in

\author{
Received: March 21, 2011; Accepted: May 10, 2011
}

\begin{abstract}
Solid-state fermentation for lipase production from Rhizopus oryzae KG-10, using different low cost available oil cakes JOC (Jatropha oil cake), TOC (Teesi oil cake), MOC (Mustard oil cake), GOC (Groundnut oil cake) was carried and it was found that the fungus produced significant amount of lipase utilizing oil cakes as substrate. Among the four substrates used crude enzyme extracted from MOC medium showed highest activity of $170 \mathrm{IU}$. Activity of enzyme extracted from medium containing JOC, TOC and GOC were assayed to be $80 \mathrm{IU}, 60 \mathrm{IU}$ and $60 \mathrm{IU}$ respectively. Total protein of the crude enzyme extracted from the different medium was estimated by Lowry's method. Total protein content of extracts from MOC, JOC, TOC and GOC medium were $32 \mathrm{mg} / \mathrm{ml}, 30 \mathrm{mg} / \mathrm{ml}, 31.2 \mathrm{mg} / \mathrm{ml}$ and $26.4 \mathrm{mg} / \mathrm{ml}$ respectively. Thus it could be seen that in about same amount of extracellular proteins the activity was maximum in case of MOC, suggesting it to be the best substrate.
\end{abstract}

Key words - Lipase, Rhizopus oryzae, oil cakes, solid-state fermentation

\section{Introduction}

Fungal lipases are known to be commercially used in various biotechnological industries. Lipases are reported in various microorganisms, animals, and plants and they breakdown lipids so they are used for various biotransformation reactions, catalysis industries and other industries e.g. detergents, dairy foods, bakery and beverages, health foods, pharmaceuticals $[1,2]$. These enzymes were well studied towards structural characterization and enzymatic action [3] but utilization of the given oil cakes as substrate for lipase production was not well reported. However, there is more emphasis towards lipase production in solid-state fermentation (SSF) because it has potential application in biotechnology industries [4]. However, SSF is most appropriate process due to its various benefits and bioconversion parameters. There are few more reports on lipase production by SSF of olive cake and sugar cane bagasse [5] and biotechnological potential of oil cakes [6]. Moreover some interesting studies on lipase production through supplemented soybean meals, statistical optimization, thermoactive alkaline lipase from Talaromyces thermophilus and optimization of lipase production in oil effluent has drawn the attention in recent years $[7,8,9,10]$. The present study gives a report of different low value oil cakes (oil cakes from Mustard, Jatropha, Groundnut and Teesi) on lipase production from Rhizopus oryzae KG10 through solid state fermentation.

\section{Materials and methods}

Microorganism and enzyme production

Rhizopus oryzae KG10 was taken for the study. It was grown on Potato-Dextrose-Agar (PDA) (Hi-media), incubated at $28^{\circ} \mathrm{C}$ for seven days and further it was stored at $4^{\circ} \mathrm{C}$. Four low cost available oil cakes obtained from local farmhouse viz. JOC (Jatropha oil cake), TOC (Teesi oil cake), MOC (Mustard oil cake), GOC (Groundnut oil cake) were used as substrate for solid state fermentation. The production medium was prepared using mineral salt solution $(20 \mathrm{ml})$ with peptone $(15 \mathrm{~g} / \mathrm{L})$, $\mathrm{NaCl}(5 \mathrm{~g} / \mathrm{L}), \mathrm{CaCl}(1 \mathrm{~g} / \mathrm{L})$ and oil cakes $(5 \mathrm{~g})$ as substrate. This was inoculated with $1 \mathrm{ml}$ of $10^{4}$ spores of R. oryzae (24 hr grown fungal culture). This was further incubated for 7 days at $30^{\circ} \mathrm{C}$.

\section{Enzyme extraction and protein estimation}

To the fermentation product $50 \mathrm{ml}$ of $0.1 \mathrm{M}$ Potassium phosphate Buffer pH 7.5 was added, stirred and mixed properly and enzyme was extracted by filtering the solution through whattman filter paper (No-1, Millipore, Carrigtwohill, Ireland). The culture filtrates obtained were centrifuged at $3000 \mathrm{xg}$ for $20 \mathrm{~min}$ and clear supernatant was collected and used as enzyme source. The enzyme activity as amount of enzyme required liberating one micromole equivalent fatty acid per $\mathrm{ml} / \mathrm{min}$. (in triplicate) was measured by titrimetric method using phenolphthalein as indicator. Soluble protein concentration and fractionated protein concentration were determined by the method of Lowry using Bovine serum albumin as standard.

\section{Concentration of Enzyme}

The crude enzyme was precipitated with ammonium sulphate. The sample was separated into five fractioned based on the saturation percent of ammonium sulphate $30 \%, 55 \%, 75 \%, 85 \%$. The precipitations were carried out at $4^{\circ} \mathrm{C}$ under constant stirring and precipitated proteins were centrifuged at $15000 \mathrm{~g}$ for 30 minute. 
The fractions were dialyzed in 0.1M Potassium phosphate Buffer ( $\mathrm{pH} 7.5)$ to remove the remaining salt.

\section{SDS-PAGE}

Sodium Dodecyl Sulpahte-Polyacrylamide gel electrophoresis (SDS-PAGE) $12 \%$ of crude and partially purified lipase was performed for the determination of molecular weight.

\section{Results and discussion}

\section{Enzyme activity and total protein}

Rhizopus oryzae KG-10 was able to produce lipase by solid-state fermentation with low value oil cakes viz. JOC, MOC, TOC and GOC upon incubation at $30^{\circ} \mathrm{C}$ for 7 days. Among the four substrates used crude enzyme extracted from MOC medium showed highest activity of $170 \mathrm{IU}$. Activity of enzyme extracted from medium containing JOC, TOC and GOC were assayed to be $80 \mathrm{IU}, 60 \mathrm{IU}$ and 60 IU respectively [Fig. 1]. Total protein of the crude enzyme extracted from the different medium was estimated by Lowry's method. Total protein content of extracts from MOC, JOC, TOC and GOC medium were $32 \mathrm{mg} / \mathrm{ml}, 30 \mathrm{mg} / \mathrm{ml}, 31.2 \mathrm{mg} / \mathrm{ml}$ and $26.4 \mathrm{mg} / \mathrm{ml}$ respectively [Fig. 2]. It can be seen that mustard oil cake was the best inducer for lipase production from KG-10.

\section{SDS-PAGE Profile}

SDS PAGE profile of all different ammonium sulphate precipitate of enzyme extract from medium containing MOC has been shown in Fig 3.

\section{Conclusion}

There are other notable reports on lipase production through SSF using oil cakes, purification, statistical optimization and use in industries $[7,8,9,10]$ and other notable reports on immobilizing the enzyme and natural selection for lipase producing microbial strains are available $[11,12]$ but there are only few reports indicating utilizing low value oil cakes as substrates mentioned in the present work. It was thus reported that mustard oil cakes (MOC) could be utilized as better substrates over other oil cakes (JOC, TOC and GOC) for lipase production from Rhizopus oryzae. This study gives an idea on utilization of waste oil cakes for enzyme production through SSF and adds value addition to oil mill wastes.

\section{Acknowledgement}

Authors are thankful to the Department of Agriculture, Government of Jharkhand for providing financial support to our department.

\section{References}

[1] Ducret A., Trani M., Lortie R. (1998) Enzyme and Microbial Technology, 22, 212-216.

[2] Zhang L.Q., Zhang Y.D., Xu L., Yang X.L., Yang X.C., Xu X.L., Wu X.X., Gao H.Y., Du W.B., Zhang X.T., Zhang X.Z. (2001) Enzyme and Microbial Technology, 29, 129-135.
[3] Nakashima T., Fukuda H., Kyotani S. and Morikawa H. (1988) Journal of Fermentation Technology, 66, 441-448.

[4] Singhania R.R., Patel A.K., Soccol C.R. and Pandey A. (2009) Biochemical Engineering Journal, 44, 13-18.

[5] Cordova J., Nemmaoui M., Ismaïli-Alaoui M., Morinc A., Roussos S., Raimbault M. and Benjilalia B. (1998) Journal of Molecular Catalysis B: Enzymatic, 5(1-4), 75-78.

[6] Ramachandran S., Singh S. K., Larroche C., Soccol C. R. and Pandey A. (2007) Oil cakes and their biotechnological applications- $A$ review, Bioresource Technology, 98, 20002009. (doi: 10.1016/ j.biortech. 2006.08.02).

[7] Rigo E., Ninow J.L., Lucciob M.D., Oliveira J.V., Polloni A.E., Remonatto D., Arbter F., Vardanega R., de Oliveira D. and Treichel $H$. (2010) LWT- Food Science and Technology, 43(7), 1132-1137.

[8] Kumar R., Mahajan S., Kumar A. and Singh D. (2011) New Biotechnology, 28(1), 65-71. (Special issues on Biocatalysis and Agricultural Biotechnology: Number 5).

[9] Belhaj-Ben Romdhane I., Fendri A., Gargouri Y., Gargouri A. and Belghith H. (2010). Biochemical Engineering Journal, 53(1), 112120 (Special Section: CHEMPOR 2008 Integration of Life Sciences and Engineering).

[10] Salihu A., Alam M. Z., Abdul Karim M. I. and Salleh H. M. (2011) Journal of Molecular Catalysis B: Enzymatic, 69(1-2), 66-73.

[11] Bapiraju K.V.V.S.N., Sujatha P., Ellaiah P. and Ramana T. (2004) African Journal of Biotechnology, 3(11), 618-621.

[12] Xin J.Y., Li S.B., Xu Y., Chui J.R. and Xia C.G. (2001) Journal of Chemical Technology and Biotechnology, 76, 579-585. 


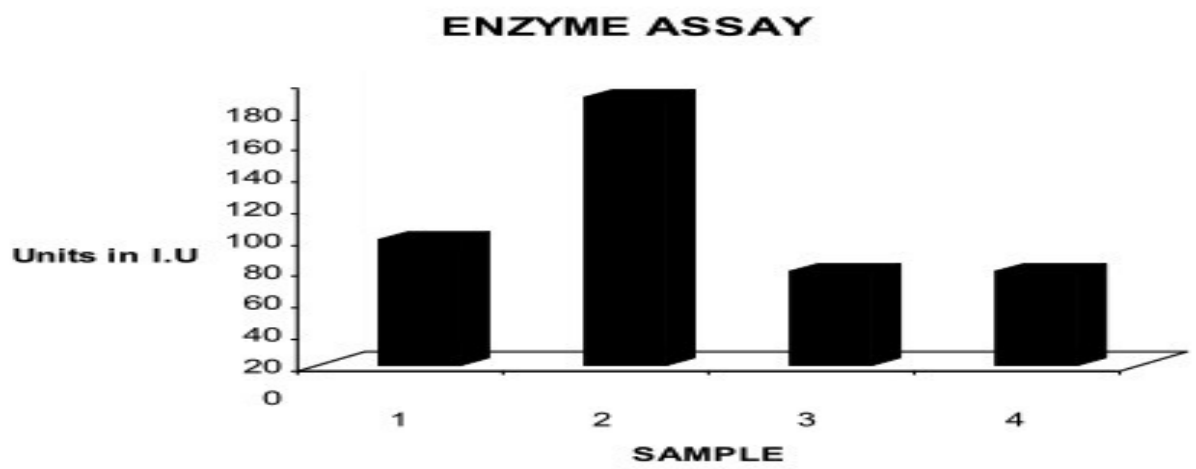

Fig. 1- Enzyme Activity (Unit/ml) for Jatropha oil cake (1); Mustard oil cake (2); Teesi oil cake (3); Groundnut oil cake (4)

\section{Total extracellular protein produced with}

different substrates

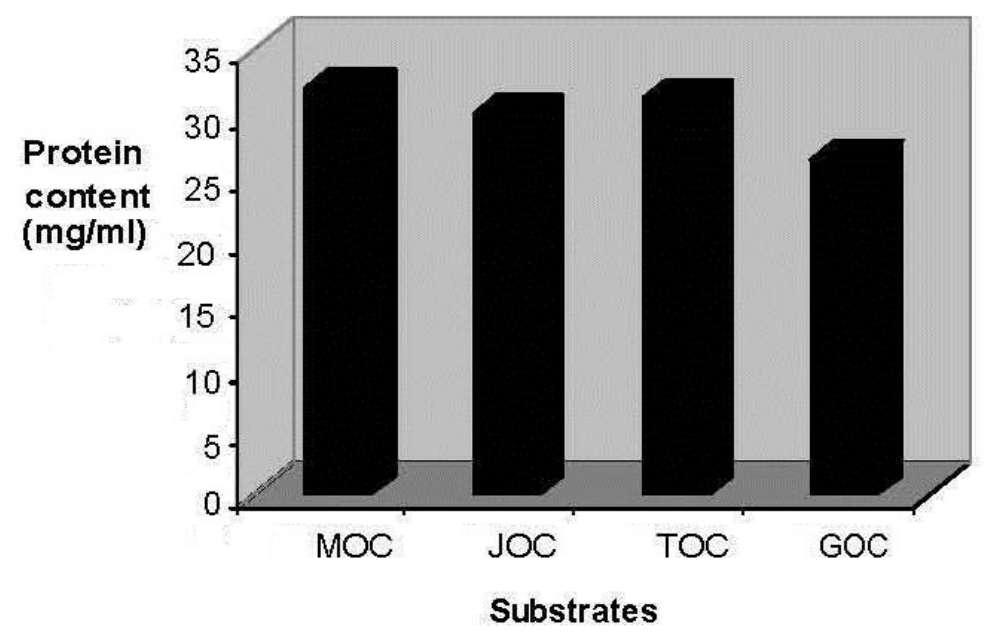

Fig. 2- Total Protein Content of the extracellular fluid on solid state fermentation with Mustard Oil cake (MOC); Jatropha Oil Cake (JOC); Teesi Oil Cake (TOC) and Groundnut Oil Cake (GOC).

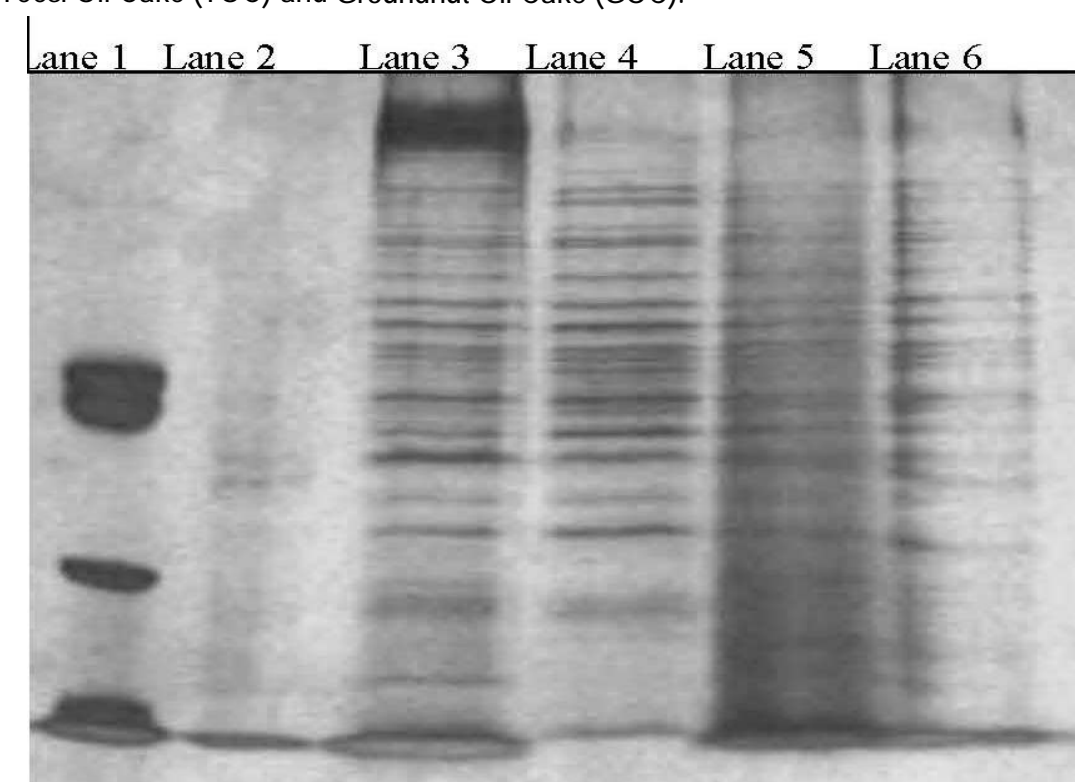

Fig. 3- SDS PAGE profile of crude and ammonium sulphate precipitate sample of Mustered oil cake (MOC). Lane1: molecular weight marker; Lane2 Crude sample, Lane 3: 30\% precipitate; Lane 4: 55\% precipitate; Lane 5: 75\%, Lane 6: $85 \%$. 